\title{
Bondowoso In the Encirclement of Private Plantation Companies in Colonial Era
}

\author{
Latifatul Izzah $^{1}$, Singgih Tri Sulistiyono ${ }^{2}$, Yety Rochwulaningsih ${ }^{3}$ \\ \{latifatul.izzah@yahoo.co.id ${ }^{1}$, singgihtrisulistiyono@gmail.com², \\ wulan.psa.undip@gmail.com $\left.{ }^{3}\right\}$ \\ 1,2,3 Universitas Diponegoro, Indonesia
}

\begin{abstract}
The purpose of this study is to analyze the environmental changes of Bondowoso regency as a result of the exploitation of the private sector from 1897 to 1928. The research location is in Bondowoso regency, the east side of East Java (Oosthoek). This study used the historical method combined with the political economy approach. The research revealed that the land leased by the Dutch was a land that was not used by the public (Woeste Gronden), and amended by the private sector into a coffee plantation and tobacco that became an excellent product in the European market. The impact caused by their private plantation company for the society that transformed from an unproductive environment into plantations provided benefits on society at Bondowoso.
\end{abstract}

Keywords: Changes in the environment, Private Sector, Regency

\section{Introduction}

In the mid-19th century, the demands of reducing the State role in the colony and the increasing role of private continuously blown from the lower house of the Dutch Parliament (Tweede Kamer der Staten General) [1]. The results can be felt in 1870 is an opportunity for foreign investors to lease the Dutch East Indies (Indonesia), whether individuals or businesses to get the right erfpacht (lease rights) protected by the colonial government. A strong legal guarantee of the colonial government in the Dutch East Indies became a stimulus for investors who had big capital to compete investing in the Dutch East Indies. The companies based in the Netherlands which is engaged in the plantation directly send representatives to major cities like Batavia, Surabaya, Medan, and Makassar to apply for the right to erfpacht the governorgeneral. Likewise with the British merchant who joined the firm vying to invest in the Dutch East Indies. As Firma Maclaine, Watson \& Co. at Batavia along with his partners namely Firma Fraser, Eaton \& Co. at Surabaya and Firma McNeill \& Co. [2]. The investors already had business experience in the plantation sector in the region of India, especially in Calcutta, Madras, and Bombay [3]. The opening up opportunities for the private sector was what will make the areas of Bondowoso underwent a dynamic environment from the unproductive environment into plantation environment of Europe (European plantation) that was not previously known by the locals.

\section{Research Method}

This study dissected using a political economy approach by John Maynard Keynes [4]. Keynes explained that when the capitalist economy was allowed to work alone without any 
regulation from the outside community and control could not utilize fully the available resources. This failure would force the government to intervene. Keynes concluded that government policies should be held to ensure their stability and the process of reproduction as well as their adequate employment. Besides, the historical methods were used to explore the impact of exploitation for environmental changes in the region of Bondowoso. The period context in this study was 1897 to 1928 . In this period, the Dutch East Indies (Indonesia) had experienced "Economic Boom" as an economic growth that increased rapidly [5]. The unproductive land and the abandoned land by the community (Woeste Gronden) [6] was rented by the colonial government to the investors and was converted to be productive land that impacted the emergence of working differentiation for local community.

\section{Result and Discussion}

\subsection{Bondowoso: Green Gold which is contested by European Investors}

The experience of the European investors both Dutch investors and British investors in the field of business particularly had good field crops in the Dutch East Indies and in India as a strong capital to expand its business octopus. One example was Birnie family, the Dutch had good experience in renting land at Sumatra and in the region of Jember [7]. Likewise, with British investors Firma Fraser-Eaton who already had a synergic business in the State of India [8]-[11]. These experiences made them hunting land into plantations to increase the coffers of gold for their company. Moreover, the investors knew how the geographical conditions of Bondowoso were very suitable to plant coffee and tobacco, and absolutely it was actually required by the European market at the time. Like a honeycomb which was contested by the investors. The investors started renting land at Bondowoso in 1897 [12]. Supported by easily obtained low-waged labors from Madura that came to Bondowoso through Panarukan port [13].

Companies that are interested to invest at Bondowoso engaged in tobacco plantations, among others [14]: 1) Besoeki Tabak Maatschappij. NV (belong to van Leeuwen Boomkamp \& Co., Amsterdam, Heerengracht 364) in Kalianyar, Tamanan, Bunder, and Pengarang; 2) Oud Djember Landbouw Maatschappij (belong to A. Van Hoboken \& Co.) in Nangkaan and Sumbersari; 3) Tabak Maatschappij NV "Kontjir" in Koncir; 4) Firm Fraser-Eaton (belong to British investors) in Klabang (Bondowoso), Sukowono with the parent company in Jember and Jelbuk and with the parent company in Jember. The tobacco plantations were set on Tabaksverordening of Besuki Governing Council on 2 September 1908 which was published in Javasche Courant in 18 and 22 September 1908, and in Tabaksverordening on May 5, 1911, no. 36 [14].

The grant of lease rights by the Dutch colonial government to the private sector has inspired farmers in the region of Bondowoso. It was proven in 1926 to 1928 that some people bought tobacco firms. This development was due to the price of tobacco on the world market was good [13]. Broad communities of tobacco were firstly harvested in 1928 and entirely odored 3.057 with details of 1.681 odored planted in the fields and 1.376 adored in the moor. Tobacco plants were harvested from growers' number 4,030 odor [13]. The above explanation proved that a change in the concept of farmers originally thought subsistence towards modern thought by planting tobacco alternately with the rice crop.

In addition to tobacco companies, investors were seeking coffee plantations to get the right 
erfpacht of the colonial government. They got the right erfpacht at Ijen high plains and on the north slope of Kendeng Mountains. These lands were not used by the public, because it was located in the highlands. The farmers only used the lowlands closed to the spring for planting rice and pulses. The company coffee plantations with large capital among others were: Belawan Kali Gedang with extensive coffee plantations in 1.308 odor, Jampit with extensive coffee plantations 375 odor, Mount Blau with extensive coffee plantations 284 odor, Kalisat with extensive coffee plantations 950 odor, Pancur and Angkrek with extensive gardens and the odor of coffee in 1.506 with an area of coffee plantations, and Kayumas with the extensive coffee plantation of 1.032 odors.

There were also some lands obtained from erfpacht rights afforded to coffee plantations with little capital, such as 1) belong to Mr. Van Dijk in the village of Sekar Putih. The extent was only 2.5 odor because it merely rented yards and fields; 2) belong to KF Douw van der Krap in Onderdistrict Curahdami Bondowoso with $8 \mathrm{R}$ and $166 \mathrm{R}$ wide, and still proposing additional measuring in $68 / 25$ odor. The land was dry land by a system of mutual profit with local people; 3) belong to YL Versteegh in Onderdistrict Sukasari, Wonosari Bondowoso. The extent was approximately 40 odor. His coffee plantation was able to change the thought of Bondowoso farmers to lease the yard and free-yard at private parties. Whereas previously the farmers let their yards and free-yard became unproductive land.

The number of investors who rent land on top of Bondowoso proved that the land was suitable to plant coffee and tobacco that produced a lot of advantages. Moreover, it was supported by facilities and infrastructure to transport it to Panarukan port to bring the production of both coffee and tobacco plantations to the European region. On the other hand, society was indirectly forced to accept changes in their environment with European plantations introduced by agribusiness crops such as coffee, tobacco, and rubber.

\subsection{The Impact of Exploitation towards Bondowoso}

It was not always negative excesses that arose as a result of exploitation in a region. It was too often that Bondowoso became a means of exploitation since Herman Willem Daendels (1808-1811) who pawned Besuki residency at the Chinese bourgeoisie to the interest of European investors (Dutch and English) for the sake of investing at the region in 1897. At the beginning of 1897-1928, Bondowoso that was in the grip of the capitalist certainly had an impact throughout the life of society. There were several sides in public life that underwent a change towards advancement in addition to changes such as the high demographics, differentiation livelihood, and advancement of transportation.

\section{Demography}

In the beginning, the number of residents in the district of Besuki (Bondowoso was part of it) was the lowest compared to other regions in Java, but after mortgaged by Herman Willem Daendels on landlords China, Besuki residency became a productive region that could create jobs in large numbers. Gradually, many people came into the area, as they were from Madura. The number of immigrants resulted in the expansion of the region by establishing a new territory called Bondowoso. In 1920, the population of the regency experienced rapid growth. Bondowoso district has amounted to 94.101 people. Tamanan district has amounted to 81.978 people. Wonosari District has amounted to 75.032 people. Prajekan district has amounted to 59.476 people. The overall population of the regency was 310.587 people [13]. The amount is already included natives, Europeans, Arabs, China and the migrants from Madura and from 
the territory of East Java. The high number of residents in the District of Bondowoso, Tamanan District, Prajekan District, and Wonosari District proved that the region territory leased by the private sector could create jobs and increased the incomes of Bondowoso. On the other hand, leasing lands that happened at Bondowoso by private parties caused ethnic and cultural mix in society.

\section{Livelihood}

Generally, Bondowoso society planted rice to meet their needs. In 1928, the area recorded 50.790 wetland entirely smell, and the smell was extensive of about 3.244 [13]. Madurese who settle at Bondowoso also planted corn in the field in addition to plant rice. They usually cook and mix the rice with corn. When European investors rented land at Bondowoso, Bondowoso community was also interested in growing tobacco in their land. Society was also working on the plantation companies belong to the European investors. Meanwhile, the Chinese people usually had a particularly large store and trading agricultural products. In Bondowoso, there were 2 rice milling companies owned by the Chinese. In the capital city of Besuki, there was 1 rice milling company owned by Arabs. The plantation company that was found by investors led to the differentiation in the areas of livelihood. The indigenous people not only plant rice, corn and other crops for subsistence purposes but also offered new jobs as laborers on the plantation companies.

\section{Transportation}

Transportation is vital for the transport of production from plantations in Bondowoso region. Dutch government provided transportation facilities to the investors who rent land in Bondowoso, such as by making the railroad. The railroad of S.S was constructed from Jember and passed through Bondowoso, and ended at Situbondo and Panarukan. Railway transport tools were used by companies plantations to transport their products like sugar, tobacco, coffee, rubber to Panarukan port, and those products would be sent to the European market. Besides, it was also used to transport rice and other crops.

The most important port on the north coast was the port of Besuki, the port of Panarukan, and port of Jangkar. Besuki port was used for cruising boat to Madura and carrying sugar from the factory Buduan and De Maas by ship. Jangkar port was only used for exporting sugar from Asembagus factory. Panarukan port was the most important port. In 1928, Panarukan Maatschappij built a new warehouse to store sugar with a capacity of 100,000. The shipping company "Bodemeijer" organized a cruise from Sumenep to Panarukan every day. People from Madura and Sapudi who came in the regency to find a job using this shipping traffic. Every ship that came in the port was already supplied by various buses that would transport them to Bondowoso, Jember, and Banyuwangi.

\section{Conclusion}

The regulation in the form of Agrarische Wet and Agrarische Besluit that was imposed in 1870 in the Dutch colonial territory brought a profit for investors who had a high capital to expand its wings to the Dutch East Indies (Indonesia). Evidently, many European investors (both Dutch and English) who experienced in the business of plantation companies flocked to the Dutch East Indies. The investors rent land that was used as well as plantation companies in 
Sumatra, Batavia, Semarang, Surabaya, and Jember. In 1897, the investors would begin to overview and learn from Bondowoso region. Legal guarantee of leased land, the fertility of lands leased, the low-salary of labor, and adequate traffic facilities especially at Panarukan port as a port that would bring estate products to the European region, became a magnet for investors to lease land in Bondowoso. The number of investors who rent land in Bondowoso impacted on environmental change, such as unproductive land into plantations of coffee and tobacco. The changes were able to improve the economy of the community at Bondowoso. The year 1928 was known as the deadline that portrayed a positive impact on people's lives at Bondowoso, and the 1897-1928 period was called the period of "economic boom". It meant that the growth of economy was rapid in Dutch Indies, especially Bondowoso as the impact of local foreign companies succession like the Dutch and the England that had invested their capital in Dutch Indies.

\section{References}

[1] A. J. D. Van Twist, Art 56 Van Het Reglement op Het Beleid der Regering van Nederlandsch Indie. Rotterdam: Otto Petri, 1863.

[2] F. Broeze, "A Scottish Merchant in Batavia (1820-1840): Gillean Maclaine and Dutch Connection," in Diaspora Entrepreneurial Networks: Four Centuries of History, disunting oleh Ina Baghdiants Mc Cabe, Gelina Harlaftis, dan Ioanna Pepelasis Minogloum, Oxford: Berg, 2005.

[3] A. Tripathi, Trade and finance in the Bengal Presidency, 1793-1833. Oxford University Press, 1979.

[4] J. M. Keynes, The general theory of employment, interest, and money. Springer, 2018.

[5] dkk Wasino, "Sejarah Nasionalisasi Aset-Aset BUMN Dari Perusahaan Kolonial Menuju Perusahaan Nasional, Biro Hukum Kementerian BUMN Republik Indonesia," 2013.

[6] J. T. Cremer, "Verspreid door Tusschenkomst van 'De Liberale Unie,"” in Koloniale Politiek, Twee redevoeringen, Haarlem H.D. Tjeenk Willink, 1891, p. 5.

[7] "Landbouw Maatschappij Oud Djember 1859-1909."

[8] D. Pradadimara, "Modal Britania di Indonesia Masa Kolonial," Mozaik Hum., vol. 16, no. 2, pp. 136-150, 2017.

[9] L. de Bree, "Gedenkboek van de Javasche Bank, 1828-1928, 2 vols," Weltevreden: Kolff, 1928.

[10] D. M. Campbell, Java: Past \& Present: a Description of the Most Beautiful Country in the World, Its Ancient History, People, Antiquities, and Products, vol. 2. W. Heinemann, 1915.

[11] U. Bosma and R. Raben, Being “Dutch” in the Indies: A history of creolisation and empire, 1500-1920, no. 116. NUS Press, 2008.

[12] V. Der Dentz \& Breggen, "Statistisch Overzicht van Sumatra en Java Tabak, Makelaar," in Tabak Amsterdam, Uitgave pp.51, 1934.

[13] A. H. Neys, "Memori Residen Bondowoso 25 April 1929," Arsip Nas. Republik Indones. Pnb. Sumber-Sumber Sej. No.10, Jakarta Arsip Nas. Republik Indones., 1978.

[14] H. Denzt, "Java Tabak 1906, Makelaar in Tabak Amsterdam,” Tweede Jaargang Maart pp.5-17 (1907), 1906. 
